\title{
ZOOPLANKTON ABUNDANCE AND BIOMASS IN A TROPICAL ESTUARY (PINA ESTUARY-NORTHEAST BRAZIL)
}

\author{
Eneida Maria ESKINAZI-SANT'ANNA \\ ICB - Laboratório de Zooplâncton - UFMG.
}

\begin{abstract}
Abundance and biomass (dry weight) contributions of the holoplankton and meroplankton were determined during diurnal tide cycles (12h) and in different seasonal periods (dry and rainy periods), in the Pina estuary (northeast Brazil). The copepods Oithona oswaldocruzi, O. hebes, Euterpina acutifrons and Parvocalanus crassirostris were the species which dominated by abundance. In the microzooplankton, Favella ehrenbergi and Brachionus plicatilis dominated. Zooplankton biomass was high, (average of $136 \mathrm{mg} \mathrm{DW} \mathrm{m}^{-3}$, with maximum of $717 \mathrm{mg} \mathrm{DW} \mathrm{m}^{-3}$ (dry period) and minimum of $4 \mathrm{mg} \mathrm{DW} \mathrm{m}^{-3}$ (rainy period). No seasonal variation was observed in biomass although significant alterations related to tides were registered in a short time period, accounting for changes in the zooplankton community. Holoplankton organisms contribuited significantly to the total biomass. Although meroplanktonic organisms occurred in reduced densities, they showed individual high biomass, especially Brachyura zoea (maximum of $52 \mathrm{mg} \mathrm{DW} \mathrm{m}^{-3}$ ) and others Decapoda zoea (35 $\mathrm{mg} \mathrm{DW}$ $\mathrm{m}^{-3}$ ), thus constituting extremely important populations in the energy dynamics of the system.

Key Words: estuary, zooplankton, density, biomass, temporal variation, tropical, Brazil.
\end{abstract}

\section{RESUMO}

Foram determinadas as contribuições em abundância e biomassa (peso seco) das frações holoplanctônicas e meroplanctônicas no estuário do Pina (Nordeste do Brasil), durante ciclos diurnos de marés (12h) e em diferentes períodos sazonais (seco e chuvoso). Os copépodos Oithona oswaldocruzi, O. hebes, Euterpina acutifrons e Parvocalanus crassirostris foram as espécies holoplanctônicas com maior contribuição numérica para o zooplâncton total. Entre o microzooplâncton, Favella ehrenbergi e Brachionus plicatilis também apresentaram densidades elevadas. A biomassa zooplanctônica foi alta (média de $136 \mathrm{mg} \mathrm{PS} \mathrm{m}^{-3}$, com máximo de $717 \mathrm{mg} \mathrm{PS} \mathrm{m}^{-3}$

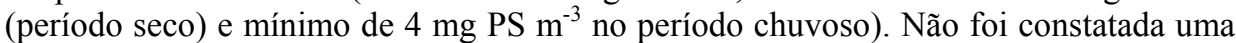
variação sazonal da biomassa, mas foram registradas alterações significativas em curto espaço de tempo, relacionadas com as correntes de marés, evidenciando as mudanças na estrutura da comunidade zooplanctônica. Os organismos holoplanctônicos apresentaram uma contribuição significativa para a biomassa total. Os organismos meroplanctônicos, apesar de ocorrerem em densidades reduzidas, apresentaram biomassa bastante elevada, destacando-se zoea de Brachyura (máximo de $52 \mathrm{mg} \mathrm{PS}^{-3}$ ) e zoeas de outros Crustacea Decapoda (35 mg PS $\mathrm{m}^{-3}$ ), constituindo-se em populações extremamente importantes na dinâmica energética do sistema.

Palavras Chave: estuário, zooplâncton, densidade, biomassa, variação temporal, tropical, Brasil. 


\section{INTRODUCTION}

During recent years, much effort has been put into studies of the role of zooplankton in estuarine systems, including spatial and temporal distributions, trophic interactions, prodution and biomass (Williams \& Collins, 1986; Tackx et al., 1994; Zaballa \& Gaudy, 1996). Zooplankton biomass is an important piece of information when estimating stored energy in the form of organic matter and for evaluation of an ecosystem production potential.

Zooplankton of estuarine systems in Brazil has been studied primarily as to the spatial-temporal distribution (Tundisi et al., 1978; Neumann-Leitão et al., 1992; Lopes, 1994; 1998). However, information on the zooplankton biomass in Brazilian estuarine systems is very scarce. Zooplankton biomass (biovolume) in the Suape estuary was first described by Neumann-Leitão (1994). Zooplankton biomass in terms of dry weight was studied by Araújo (1996) in the estuary of the Piauí and Fundo Rivers (northeast Brazil) and by Ara (1998), in the Cananéia estuary (southeast Brazil).

In this study, the density and biomass contribution of meroplankton and holoplankton were quantified in an attempt to describe daily and seasonal changes in the two main components of the zooplankton community in the Pina estuary.

\section{STUDY AREA}

The Pina estuary is located in the urban area of Recife (northeast Brazil) $\left(08^{\circ} 04^{\prime} 03^{\prime \prime}-08^{\circ} 05^{\prime} 06^{\prime \prime} \mathrm{S}\right.$ and $\left.034^{\circ} 52^{\prime} 16^{\prime \prime}-034^{\circ} 53^{\prime} 58^{\prime \prime} \mathrm{W}\right)$, and is formed by the confluence of Capibaribe, Tegipió, Jordão and Pina rivers. The total area comprises 3,6 $\mathrm{km}^{2}$, with width varying from 0.26 and $0.86 \mathrm{~km}$ (Figure 1). The maximum depth is 4.5 $\mathrm{m}$ and the tide regime is semi-diurnal with maximum amplitude of $3.5 \mathrm{~m}$ during high tide. Due to the fast process of urban occupation along the estuary, the mangrove forest which originally bordered the Pina estuary was cut down in recent years.

The climate conditions in the region can be characterized by the occurrence of two annual periods: the dry period (September to February) $(<100 \mathrm{~mm} / \mathrm{month})$ and a rainy period (March to August) ( $>200 \mathrm{~mm} / \mathrm{month}$ ). Average annual temperature is $26^{\circ} \mathrm{C}$ with high thermal homogeneity along the year.

\section{MATERIALS AND METHODS}

Plankton sampling was done from a fixed station in the central region of the estuary (Figure 1) during the dry (January and February) and rainy period (June and July) of 1991. Samples were collected during the day (5 a.m. to 5 p.m.) every 3 hours totaling a 12 hour-tidal cycle.

Zooplankton samples were obtained collecting surface water with a Van Dorn bottle, and filtering the water (2001) through a $69 \mu \mathrm{m}$ mesh nylon. One sampling was done for biomass determination and another for zooplanktonic density. All of the samples were preserved in a $4 \%$ buffered formaldehyde solution.

For quantitative analysis, subsamples of 1-4 ml were taken from the original sample $(150 \mathrm{ml})$ with a Stempel pipette, and organisms were counted on a stereomicroscope. Holo- and meroplanktonic organisms were sorted with the aid of a binocular stereomicroscope, then washed with distilled water and put in pre-weighted aluminum combustion vessels for obtaining biomass. The number of organisms on each 
vessel varied from 20 to 30 , according with the number of specimens available in the sample. The organisms were measured in a binocular stereomicroscope equipped with eye-piece micrometer.

Vessels which contained the micro- and mesozooplankton species were dried in an oven at $60^{\circ} \mathrm{C}$ for 24 hours, while for macrozooplankton, including Brachyura and Decapoda zoea, fish eggs and larvae, vessels were dried at $110^{\circ} \mathrm{C}$, according to Winberg (1971). A Mettler microbalance 22/BA25 ( $\pm 0,1 \mu \mathrm{g})$, was used for determination of zooplankton dry weight. Weight loss due to formaldehyde was not considered, according to Chisholm \& Roff (1990).

Environmental parameters of the estuary, including water transparency, temperature, $\mathrm{pH}$, salinity and oxygen concentrations were described in EskinaziSant'Anna \& Tundisi (1996).

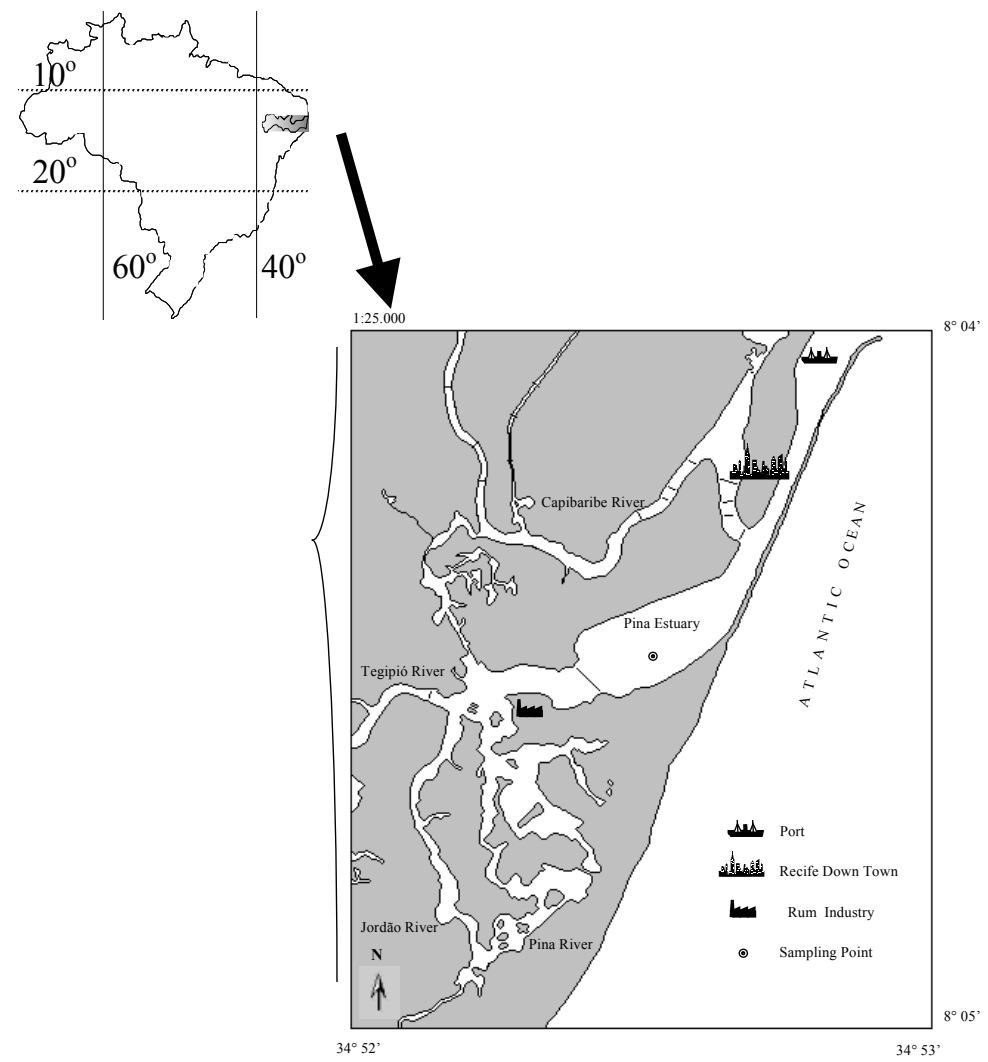

Figure 1. Pina estuary, northeast Brazil, showing sampling station. 


\section{RESULTS}

\section{Zooplankton Composition and Abundance}

Among the zooplankton organisms found in the Pina estuary the following estuarine and estuarine/marine copepod species were prominent: Oithona oswaldocruzi, Oithona hebes, Paracalanus quasimodo, Parvocalanus crassirostris and Euterpina acutifrons. Females of the copepod Oithona oswaldocruzi were the only organisms which occurred along the seasonal periods studied and in all tidal cycles. It is thus a permanent species of this estuary together with Euterpina acutifrons.

Meroplanktonic forms were also recorded, including Brachyura and Decapoda zoea, Balanus spp. and Polychaeta larvae, which showed a very irregular temporal pattern of occurrence during the period of study. The holoplanktonic organisms constituted more than $60 \%$ of total zooplankton. Meroplankton represented less than $30 \%$ of total zooplankton except for one sample in the rainy period in which the nauplii of Balanus and zoea of Brachyura were more abundant (>50\%) (Figure 2).

During the dry period, the abundance of the microzooplankter Favella ehrenbergi was high (during some tidal levels, comprise more than $79 \%$ of all zooplankton community). Another holoplanktonic microzooplankter with high percentual abundance was Brachionus plicatilis (almost $65 \%$ of total zooplankton during the dry period (February) and up to $43 \%$ during the rainy period (June). Copepods also were present in high abundance, mainly Oithona oswaldocruzi and Oithona hebes (especially during the dry period).

The zooplankton density in the Pina estuary had significant variations along the daily tidal cycle, reflecting the influence of hydrodynamic process in the distribution of planktonic community. The number of taxa found during the dry period was considerably (minimum of 11 and maximum of 18 taxa). During the rainy period a considerable increase in the number of taxa in the estuary was observed, especially in June. During this month a minimum of 7 and maximum of 27 taxa were recorded especially because of the occurrence of non-resident copepods such as Notodiaptomus cearensis and Pseudodiaptomus acutus, and the seasonal occurrence of Eucalanus pileatus, Centropages velificatus and Hemicyclops thalassius, besides Polychaeta larvae.

\section{Zooplankton Biomass}

The zooplankton biomass also exhibited oscillations along the sampling period either in short time scale (hours) or in longer scale (seasonal), with a maximum of 717 $\mathrm{mg} \mathrm{DW} \mathrm{m} \mathrm{m}^{-3}$ (february - dry period) and minimum of $4 \mathrm{mg} \mathrm{DW} \mathrm{m}^{-3}$ (july - rainy period) (global average biomass of $136 \mathrm{mg} \mathrm{DW} \mathrm{m}^{-3}$ ). (Figures 3 and 4). The individual dry weight of the zooplankton species also showed seasonal variations, affecting the global biomass values. For meroplanktonic forms, the range of individual dry weight was considerable. Individual dry weight of Mollusca larvae p. e., ranged from 15 to $24 \mu \mathrm{g}$, while for Fish (eggs and larvae), individual dry weight varied from 42 to $293 \mu \mathrm{g}$. Individual dry weight of holoplanktonic copepods was more stable, especially for Oithona osvaldocruzi $(3 \mu \mathrm{g})$, Oithona hebes $(2 \mu \mathrm{g})$ and Parvocalanus crassirostris (from 2 to $3 \mu \mathrm{g})$. (Table 1$)$. 


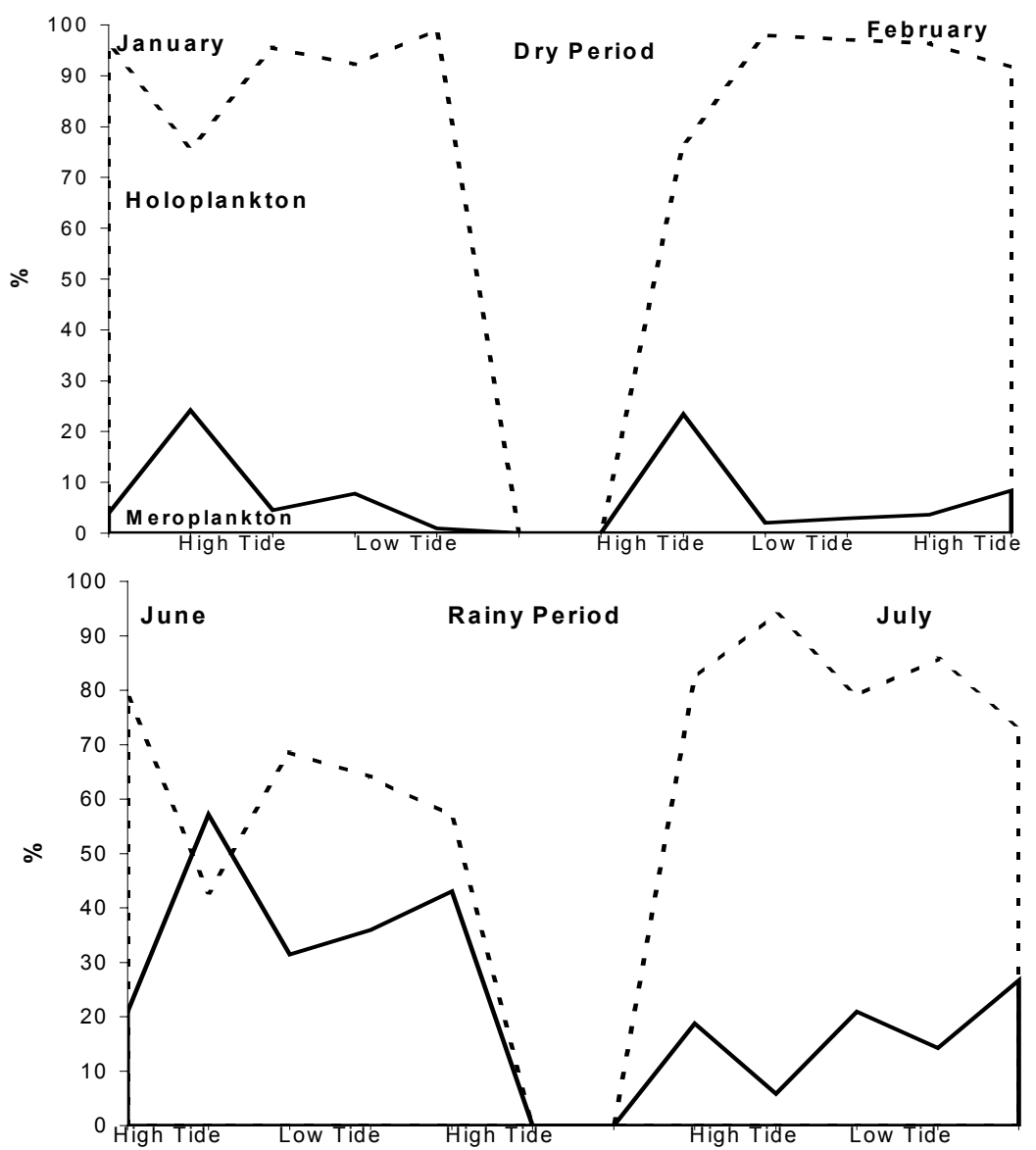

Figure 2. Holoplankton and meroplankton density (\%) in the Pina estuary. 

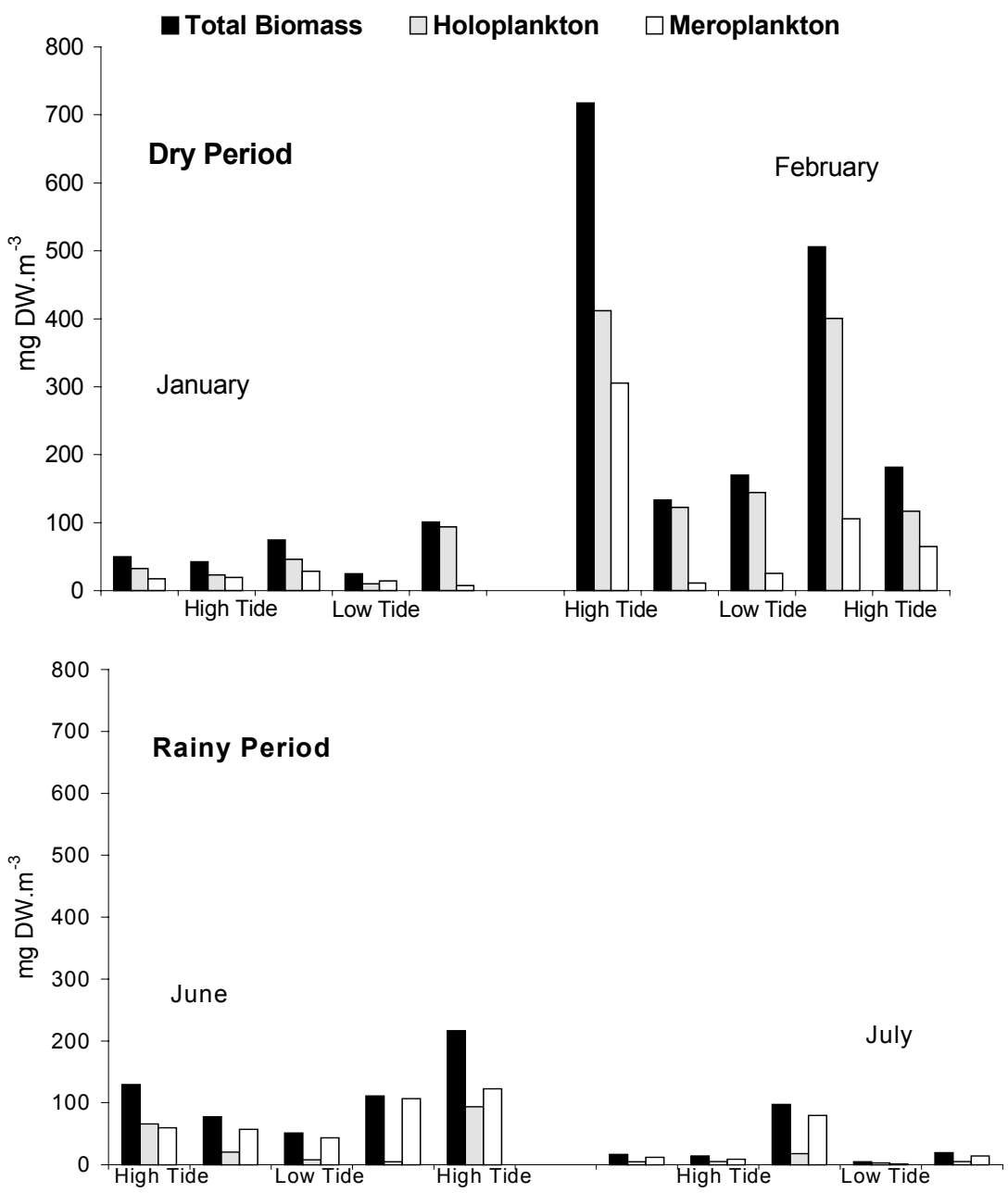

Figure 3. Diurnal and seasonal variation of zooplankton biomass (mg DW. $\mathrm{m}^{-3}$ ) 


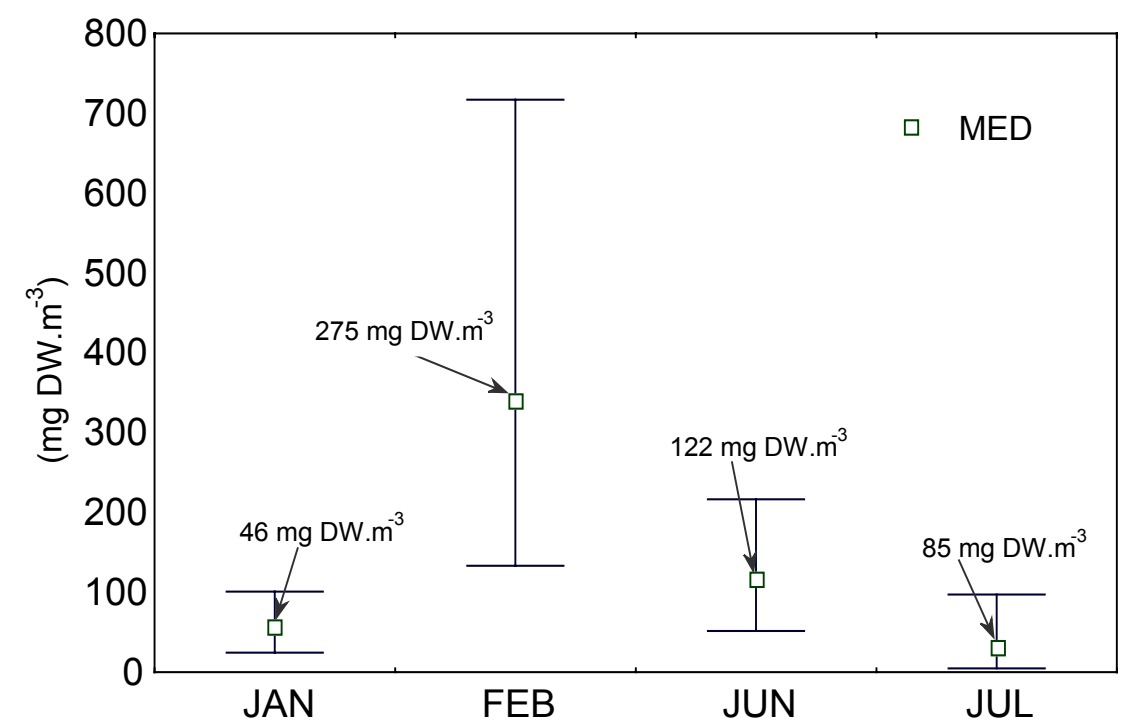

Figure 4. Zooplankton biomass range (maximum, minimum and monthly average) in the Pina estuary.

The highest biomass among the holoplankton was recorded for Copepoda, especially during the dry period (Figure 5), due to the quantitative peaks of the species Oithona oswaldocruzi ( and ) and Oithona hebes $(\mathbf{)})$. The biomass of the rotifer Brachionus plicatilis was also high in some samples (maximum of $123 \mathrm{mg} \mathrm{DW} \mathrm{m}^{-3}$ ).

Although the percentage contribution of meroplanktonic organisms was small, their biomass was considerable, even when they made up to less than $5 \%$ of the zooplanktonic community, especially Brachyura and other Decapoda zoea and Polychaeta larvae (Figure 5).

In terms of distribution of biomass in size classes, there was a concentration between 200 and $800 \mu \mathrm{m}$ in the two periods (Figure 6). This happened because of the seasonal occurrence of some organisms, especially meroplanktonic larvae which in general have larger body size. A more uniform distribution in size classes was observed only during February (dry period), when microzooplankton was more abundant, especially Brachionus plicatilis and Copepoda nauplii. 
Table 1. Zooplankton integrated biomass (B) $\left(\mathrm{mg} \mathrm{DW} \mathrm{m}^{-3}\right)$ and individual dry weight (IDW) ( $\mu$ g), during the dry (january and february) and rainy period (june and july). $\mathrm{ND}=$ not determined. Values in brackets represent the standard desviation.

\begin{tabular}{|c|c|c|c|c|c|c|c|c|}
\hline \multirow[t]{3}{*}{ PERIOD } & \multicolumn{4}{|c|}{$\overline{\mathrm{DRY}}$} & \multicolumn{4}{|c|}{ RAINY } \\
\hline & \multicolumn{2}{|c|}{ JANUARY } & \multicolumn{2}{|c|}{ FEBRUARY } & \multicolumn{2}{|c|}{ JUNE } & \multicolumn{2}{|c|}{ JULY } \\
\hline & B & IDW & B & IDW & $\mathbf{B}$ & IDW & B & IDW \\
\hline \multicolumn{9}{|l|}{ MEROPLANKTON } \\
\hline Polychaeta Larvae & & & & & 39.0 & $47.0(17.79)$ & 11.0 & $53.0(25.71)$ \\
\hline Mollusca larvae & 6.0 & $15.0(7.39)$ & 16.0 & $16.0(2.51)$ & 12.0 & $22.0(4.30)$ & 4.0 & $24.0(0.00)$ \\
\hline Balanus spp (nauplius and cypris) & 2.0 & $3.0(0.90)$ & 5.0 & $4.0(2.55)$ & 8.0 & $4.0(2.06)$ & 2.0 & $5.0(2.80)$ \\
\hline Brachyura zoea & 10.0 & $17.0(2.68)$ & 52.0 & $19.0(2.16)$ & 8.0 & $14.0(2.45)$ & 7.0 & $18.0(2.83)$ \\
\hline Others Decapoda zoea & & & 35.0 & $93.0(0.10)$ & & & 22.0 & $117.0(0.10)$ \\
\hline Fish (eggs and larvae) & & & 42.0 & $293.0(2.20)$ & 12.0 & $42.0(37.30)$ & 24.0 & $130.0(0.00)$ \\
\hline TOTAL MEROPLANKTON & 18.0 & & 150.0 & & 79.0 & & 70.0 & \\
\hline \multicolumn{9}{|l|}{ HOLOPLANKTON } \\
\hline Centropyxis aculeata & ND & & ND & & ND & & ND & \\
\hline Favella ehrenbergi & ND & & ND & & ND & & ND & \\
\hline Brachionus plicatilis & 1.0 & $1.0(0.10)$ & 46.0 & $1.0(0.15)$ & 1.0 & $1.0(0.10)$ & 1.0 & $1.0(0.10)$ \\
\hline Penilia avirostris & & & & & & & 1.0 & $3.0(0.00)$ \\
\hline Moina $\mathrm{sp}$ & & & & & 1.0 & $2.0(0.10)$ & 1.0 & $2.0(0.40)$ \\
\hline Copepod Nauplii & 1.0 & $1.0(0.10)$ & 5.0 & $1.0(0.10)$ & 1.0 & $1.0(0.00)$ & 1.0 & $1.0(0.00)$ \\
\hline Eucalanus pileatus & & & & & 2.0 & $13.0(3.69)$ & & \\
\hline Paracalanus quasimodo & 3.0 & $5.0(0.17)$ & 6.0 & $4.0(0.53)$ & 2.0 & $4.0(0.38)$ & 1.0 & $2.0(0.00)$ \\
\hline Paracalanus indicus & 3.0 & $5.0(0.10)$ & 3.0 & $4.0(0.10)$ & 2.0 & $4.0(1.41)$ & 1.0 & $3.0(0.10)$ \\
\hline Parvocalanus crassirostris & 1.0 & $2.0(0.23)$ & 5.0 & $2.0(0.55)$ & 1.0 & $3.0(0.87)$ & 1.0 & $2.0(0.21)$ \\
\hline Centropages velificatus & & & & & 3.0 & $12.0(3.84)$ & & \\
\hline Notodiaptomus cearensis & & & & & & & 1.0 & $18.0(0.00)$ \\
\hline Pseudodiaptomus acutus & & & & & 2.0 & $10.0(2.37)$ & 1.0 & $9.0(1.41)$ \\
\hline Labidocera fluviatilis & & & & & 4.0 & $21.0(0.92)$ & & \\
\hline Acartia lilljeborgi & & & 2.0 & $5.0(0.10)$ & 7.0 & $3.0(1.91)$ & 2.0 & $10.0(0.10)$ \\
\hline Oithona oswaldocruzi & 13.0 & $3.0(0.60)$ & 40.0 & $3.0(0.37)$ & 8.0 & $3.0(0.44)$ & 1.0 & $3.0(0.50)$ \\
\hline Oithona hebes & 4.0 & $2.0(0.48)$ & 14.0 & $2.0(0.39)$ & 1.0 & $2.0(0.27)$ & 1.0 & $2.0(0.34)$ \\
\hline Hemicyclops thalassius & & & & & 1.0 & $2.0(0.20)$ & 1.0 & $2.0(0.90)$ \\
\hline Euterpina acutifrons & 2.0 & $3.0(0.83)$ & 4.0 & $2.0(0.73)$ & 1.0 & $2.0(0.34)$ & 1.0 & $2.0(0.40)$ \\
\hline Sagitta sp & & & & & 6.0 & $22.0(5.60)$ & & \\
\hline TOTAL HOLOPLANKTON & 28.0 & & 125.0 & & 43.0 & & 15.0 & \\
\hline TOTAL ZOOPLANKTON & 46.0 & & 275.0 & & 122.0 & & 85.0 & \\
\hline
\end{tabular}




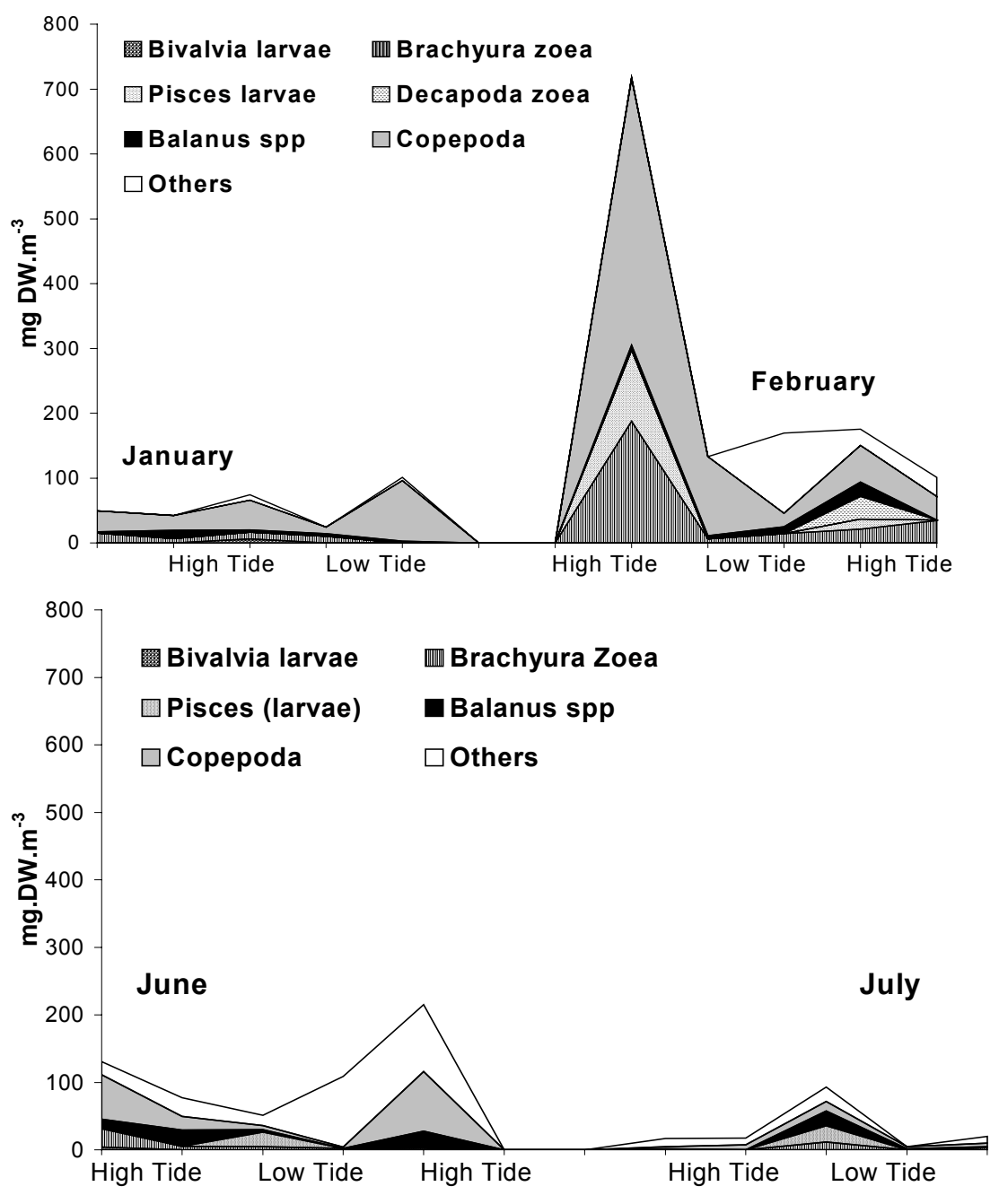

Figure 5. Zooplankton biomass composition during the dry and rainy periods 


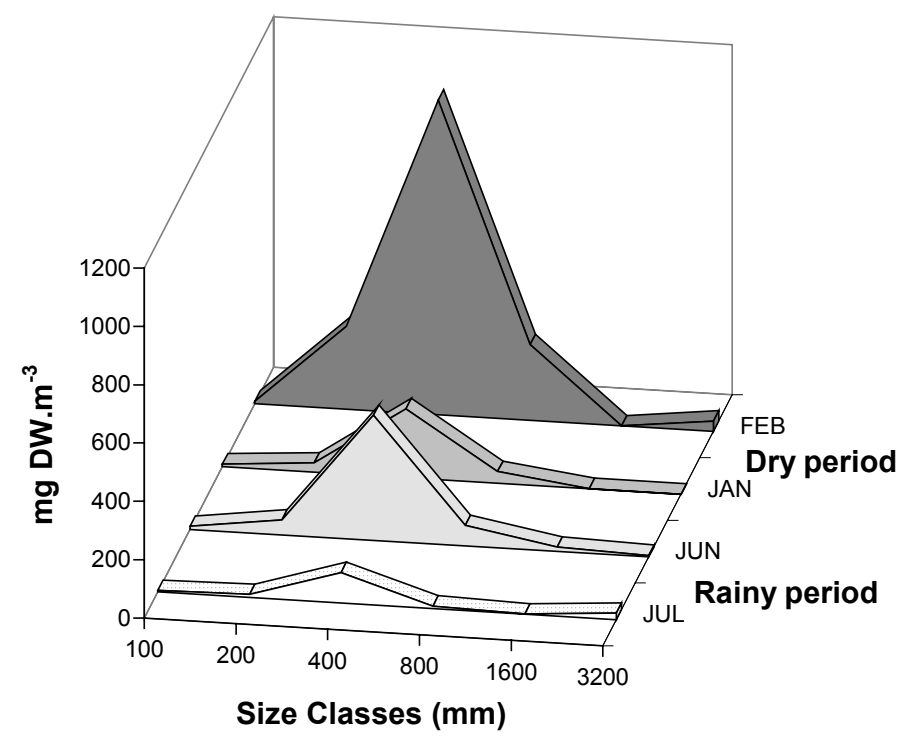

Figure 6. Biomass size-class distribution in the zooplankton of the Pina estuary

\section{DISCUSSION}

Estuaries are characterized by their environmental gradients, both temporally and spatially (Day Jr. et al., 1989). According to Eskinazi-Sant'Anna \& Tundisi (1996), the most pronounced temporal gradients in Pina estuary are transparency and salinity, which are controlled by seasonal forcing . During the dry period, the stratification of water is more prominent, because rainfall and river flux into the estuary are lower and influence of coastal waters is stronger. During the rainy period, the flux of freshwater into the estuary changes substantially the patterns of salinity and transparency. These seasonal environmental changes result in decrease in the density of resident species and carrying of some freshwater species to the estuary (e.g. Moina sp, Pseudodiaptomus acutus and Notodiaptomus cearensis), modifying the zooplankton composition.

The zooplankton in the estuary was dominated by holoplanktonic forms, especially the copepods Oithona osvaldocuzi, Oithona hebes, Parvocalanus crassirostris, Paracalanus quasimodo and Euterpina acutifrons. The strongest characteristic of the Pina estuary were the high daily and seasonal fluctuations in the composition and abundance of nearly all organisms. In general, euryhaline species were the most frequently observed group. The distribution of some of these species such as Paracalanus indicus and Paracalanus quasimodo was associated with the periods of high tide, when coastal waters exert stronger influence. Similar results were obtained in other Brazilian estuarine systems (Bonecker, 1995; Lopes et al.,1998).

Among the microzooplankton forms, tintinnids and rotifers showed quantitative peaks, making up a significant portion of total zooplankton. A similar 
pattern was found by Neumann-Leitão et al., (1992), in the Suape estuary and by Lopes (1994), in the Guaraú river estuary. At Pina Estuary only one tintinnid species $(F$. ehrenbergi) and one rotifer species (B. plicatilis) were found. This is a rare pattern if compared to other Brazilian estuarine systems (Lansac Tôha \& Lima, 1993; NeumannLeitão, 1994). The absence of other species can be attributed to the sampling method (nylon of $69 \mu \mathrm{m}$ mesh aperture), since tintinnids and rotifers are more efficiently collected with nets of smaller meshes - 25 to $50 \mu \mathrm{m}$ (Souto, 1981; Nogrady et al., 1993).

Meroplanktonic forms were represented by a small number of species, including Balanus spp (nauplii and cypris), Decapoda and Brachyura zoea and Polychaeta larvae. According to Christy \& Stancyk (1982) and Dame \& Allen (1996), invertebrate larvae can display active transport and move either horizontally or vertically in the water column taking advantage of the tidal currents. The low depth of the estuary $(<4 \mathrm{~m})$ can also facilitate the occurrence of meroplanktonic forms in surface layers of the water column.

Brachyura and other Decapoda zoea, in addition to fish eggs and larvae, were not abundant and their occurrence was restricted and seasonal. These facts seem to indicate that unfavorable conditions could be affecting the recruitment of adult populations in the estuary.

During the rainy period, the density of copepods in the Pina estuary was slightly reduced. The reason for that was probably the decrease in salinity by virtue of river discharge and reduced food availability. The presence of freshwater in the estuary during the rainy period increased water turbidity, thus limiting phytoplankton growth. Feitosa (1988) found a decrease in chlorophyll $a$ of more than $50 \%$ during the rainy period.

In the Pina estuary, copepod diversity was higher in the rainy period (13 species), mainly due to the seasonal occurrence of Eucalanus pileatus, Centropages velificatus, Notodiaptomus cearensis, Pseudodiaptomus acutus, Labidocera fluviatilis and Hemicyclops thalassius. The species E. pileatus is frequently found in highly turbid coastal waters, where it can ingest suspended particles (Turner, 1984; Tester \& Turner, 1988). The distribution of $C$. velificatus in estuarine waters occurs largely because of the type of food spectra, since this species exhibits essentially a carnivorous behavior, although according to Turner (1987) other items can be part of its diet (phytoplankton and detritus). The occurrence of $N$. cearensis and P. acutus in the estuary is probably due to the freshwater input, which considerably reduces the salinity in the central region of the estuary allowing them to be distributed in an extend area.

Copepod nauplii of a wide variety of species (not listed) were observed in the Pina estuary, especially of Euterpina acutifrons and Oithona spp, which occurred in appreciable amounts. Nauplii are considered to be an important component of the marine trophic web, because they are the prey of ichthyoplankton and other planktonic consumers (Roff et al., 1995). This result confirms that Oithona osvaldocruzi and E. acutifrons are resident species of the estuary and are present not only because of passive transport in tidal currents but also because of reproduction in the area.

\section{Zooplankton Biomass}

Biomass values in the Pina Estuary were high (average of $136 \mathrm{mg} \mathrm{DW} \mathrm{m}^{-3}$ ), similar to those found by Araújo (1996), in another tropical estuary, also in Northeast 
Brazil (between 49 and $170 \mathrm{mg} \mathrm{DW} \mathrm{m} \mathrm{m}^{-3}$ ).

In Brazilian coastal waters, the reported zooplanktonic biomass values are lower than those obtained at the Pina estuary, although they had been described in areas of large biological production. Valentin \& Moreira (1978) obtained zooplankton biomass between 50 and $>200 \mathrm{mg} \mathrm{DW} \mathrm{m}^{-3}$ in upwelling waters in Southeast Brazil with expressive seasonal variation. In wave breaking zones in the South coastal shelf in Brazil, the biomass can vary seasonally between $39.7 \mathrm{mg} \mathrm{DW} \mathrm{m}^{-3}$ and $189.2 \mathrm{mg} \mathrm{DW} \mathrm{m}^{-}$ 3 (Bersano, 1994).

Raymont (1983) and Petipa (1979) consider that tropical regions can have seasonal variations but characterize them as low production areas. However, in estuaries located in temperate and subtropical regions, biomass values similar to those found in the Pina estuary were recorded - between 50 and 200 $\mathrm{mg} \mathrm{DW} \mathrm{m}^{-3}$ (Rodríguez \& Mullin, 1986; Buskey, 1993; Soetaert \& Van Rijswijk, 1993; Bakker e Van Rijswijk, 1994; Escaravage \& Soetaert, 1995).

According to Chisholm \& Roff (1990), higher biomass values in tropical coastal waters can result from a condition in which food availability is continuous without inter-annual alterations, favoring zooplanktonic populations along the year. In tropical regions, biomass and secondary zooplankton production can exhibit a seasonal effect, but the values are very close to those observed for temperate regions.

In the Pina estuary, the holoplankton biomass was considerable, specially the copepod biomass. However, a different pattern was observed for the meroplanktonic forms. Even in reduced densities, they represented an important source of biomass, and seem to have an essential role in the biological production of the Pina estuary, can be considered, therefore, as fundamental elements in the energy dinamics of the system.

\section{ACKNOWLEGMENT}

The author would like to thank Prof. José Galízia Tundisi for his advisorship during this study and FAPESP for financial support (90/1478-8). Thanks are also due to Prof. Tagea K.S. Björnberg and Dr. Rubens Lopes for the suggestions on the manuscript. The author is grateful to the reviewer for the carefully revision and suggestions.

\section{REFERENCES}

ARAÚJO, H.M.P. 1996. Zooplâncton dos estuários dos rios Piauí e Fundo (Sergipe, Brasil): flutuações espaciais, sazonais e tidais. Ph.D. Thesis. Universidade Federal do Paraná. 191p.

ARA, K. 1998. Variabilidade temporal e produção dos copépodos no complexo estuarino-lagunar de Cananéia, São Paulo, Brasil. Ph.D. Thesis. University of São Paulo. 308p.

BAKKER, C. \& VAN RIJSWIJK, P. 1994. Zooplankton biomass in the Oosterschelde (SW Netherlands) before, during and after the construction of a storm-surge barrier. Hydrobiologia, 282/283: 127-143.

BERSANO, J.G. 1994. Zooplâncton da zona de arrebentação de praias arenosas, situadas ao sul de Rio Grande (RS). Primavera de 1990, verão de 1991. M.Sc. Thesis. Universidade de Rio Grande. 163p.

BONECKER, S.L.C. 1995. Dinâmica do zooplâncton no sistema estuarino do Rio 
Mucuri (BA). Ph.D. Thesis. Universidade de São Paulo. 154p.

BUSKEY, E.J., 1993, Annual pattern of micro-and mesozooplankton abundance and biomass in a subtropical estuary. J. Plankton Res., 15: 907-924.

CHISHOLM, L.A. \& ROFF, J.C. 1990. Size-weight relationships and biomass of tropical neritic copepods. Mar. Biol., 106: 71-77.

CHRISTY, J.H. \& STANCYK, S.E. 1982. Timing of larval production and flux of invertebrate larvae in a well-mixed estuary. In Kennedy, V.S., ed. Estuarine Comparisons, Academic Press, New York. p. 489-503.

DAME, R.F. \& ALLEN, D.M. 1996. Between estuaries and the sea. J. exp. mar. Biol. Ecol., 200: 169-185.

DAY JR., J.W.; HALL, C.A.S.; KEMP, W.M. \& YÁÑEZ-ARANCIBIA, A. 1989. Estuarine Ecology. New York, John Wiley \& Sons, 558p.

ESCARAVAGE, V. \& SOETAERT, K. 1995. Secondary production of the brackish copepod communities and their contribution to the carbon fluxes in the Westerschelde estuary (The Netherlands). Hydrobiologia, 311: 103-114.

ESKINAZI-SANT’ANNA, E.M. \& TUNDISI, J.G. 1996. Zooplâncton do estuário do Pina (Recife-Pernambuco-Brasil): composição e distribuição temporal. Rev. bras. oceanogr., 44: 23-33.

FEITOSA, F. A. N. 1988. Produção primária do fitoplâncton relacionada com parâmetros bióticos e abióticos na Bacia do Pina (Recife-Pernambuco-Brasil). M.Sc. Thesis, Universidade Federal de Pernambuco. 270p.

LANSAC TÔHA, F.A. \& LIMA, A.F. 1994. Ecologia do zooplâncton do estuário do rio Una do Prelado (São Paulo, Brasil). Acta Limnol. Bras., VI: 82-96.

LOPES, R.M. 1994. Zooplankton distribution in the Guaraú river estuary (South-eastern Brazil). Estuar. coast. shelf Sci., 39: 287-302.

LOPES, R.M.; VALE, R.; BRANDINI, F.P. 1998. Zooplankton composition, abundance and spatial distribution in the estuarine complex of Paranaguá during winter 1993 and summer 1994. Rev. bras. oceanogr., 46: 195-211.

NEUMANN-LEITÃO, S.N.; PARANAGUÁ, M.; VALENTIN, J.L. 1992. The planktonic rotifers of the estuarine lagunar complex of Suape (Pernambuco-Brasil). Hydrobiologia, 232: 133-143.

NEUMANN-LEITÃO, S. 1994. Impactos antrópicos na comunidade zooplanctônica estuarina. Porto de Suape-PE-Brasil. Ph.D. Thesis. Universidade de São Paulo. 273p.

NOGRADY, T.; WALLACE, R.L. \& SNELL, T.W. 1993. Rotifera: Biology, Ecology and Systematics. In Nogrady, T. (ed). Guides to the Identification of the Microinvertebrates of the Continental Waters of the World, London, SPB Academic Publishing. 140p.

PETIPA, T.S. 1979. Trophic relationships in communities and the functioning of marine ecosystems: I. Studies in trophic relationships of the southern seas of the USSR and in the tropical Pacific. In Dubar, M.J. (ed). Marine production mechanisms, Cambridge, Cambridge University Press. 338p.

RAYMONT, J.E.G. 1983. Plankton and productivity in the oceans.2.Zoplankton. Oxford, Pergamon Press. 824pp.

RODRÍGUEZ, J. \& MULLIN, M.M. 1986. Diel and interannual variation of size distribution of oceanic zooplanktonic biomass. Ecology, 67: 215-222. 
ROFF, J.C.; TURNER, J.T.; WEBBER, M.K.\& HOPCROFT, R.R. 1995. Bacterivory by tropical copepod nauplii: extent and possible significance. Aquat. microb. ecol., 9: $165-175$.

SOETAERT, K. \& VAN RIJSWIJK, P.V. 1993. Spatial and temporal patterns of the zooplankton in the Westerschelde estuary. Mar. Ecol. Prog. Ser., 97: 47-59.

SOUTO, S. 1981. Tintinnina. In Boltovskoy, D. (ed). Atlas del zooplacton del Atlántico Sudoccidental y métodos de trabajo com el zooplancton marino. Mar del Plata, INIDEP. 936p.

TACKX, M.L.M.; HERMAN, P.M.J.; VAN RIJSWIJK, P.; VINK, M. \& BAKKER, C. 1994. Plankton size distributions and trophic relations before and after the construction of the storm-surge barrier in the Oosterschelde estuary. Hydrobiologia, 282/283: $145-152$.

TESTER, P. A. \& TURNER, J.T. 1988. Comparative carbon-specific ingestion rates of phytoplankton by Acartia tonsa, Centropages velificatus and Eucalanus pileatus grazing on natural phytoplankton assemblages in the plume of the Mississippi River (northern Gulf of Mexico continental shelf). Hydrobiologia, 167/168: 211-217.

TUNDISI, J.G.; TEIXEIRA, C.; MATSUMURA-TUNDISI, T.; KUTNER, M.B. \& KINOSHITA, L. 1978. Plankton studies in a mangrove environment.IX.Comparative investigations with coastal oligotrophic waters. Rev. Bras. Biol., 38: 301-320.

TURNER, J.T. 1984. Zooplankton feeding ecology: contents of fecal pellets of the copepods Eucalanus pileatus and Paracalanus quasimodo from continental shelf waters of the Gulf of Mexico. Mar. Ecol. Prog. Ser., 15: 27-46.

TURNER, J.T. 1987. Zooplankton feedin ecology: contents of fecal pellets of the copepod Centropages velificatus from waters near the mouth of the Mississippi River. Biol. Bull., 173: 377-386.

VALENTIN, J. \& MOREIRA, A.P. 1978. A matéria orgânica de origem zooplanctônica nas águas de ressurgência de Cabo Frio (Brasil). An. Acad. Brasil. Ciênc., 50: 103112.

WILLIAMS, R. \& COLLINS, N.R. 1986. Seasonal composition of meroplankton and holoplankton in the Bristol Channel. Mar. Biol., 92: 93-101.

WINBERG, G. 1971. Methods for the estimation of production of aquatic animals. London, Academic Press. 175pp.

ZABALLA, J.D. \& GAUDY, R. 1996. Seasonal variations in the zooplankton and in the population structure of Acartia tonsa in a very eutrophic area: La Habana Bay (Cuba). J. Plankton Res., 18: 1123-1135. 